\title{
Judicial Intervention in Admission Decisions of Private Professional Associations
}

Francis Ascherman, a licensed and practicing physician on the staffs of several hospitals in the San Francisco area, wanted to practice at a hospital closer to his home office, so he applied for staff membership at the privately run Saint Francis Memorial Hospital. ${ }^{1}$ The hospital summarily rejected Ascherman's application, without a hearing, because he had not obtained three letters of recommendation from active members of the Saint Francis staff, as required by one of its by-laws. Ascherman sued the hospital, alleging that the rule was unfair and contending that the hospital had to consider his qualifications based on the evidence he presented in his application. ${ }^{2}$ The California Court of Appeal held that the by-law violated minimal common law standards of fair procedure and directed that an injunction be issued compelling Saint Francis to reconsider. Ascherman's application "pursuant to a fair procedure."s

The Ascherman case is the most radical departure to date from the long-standing position of American courts that admission decisions of private professional associations are not subject to judicial scrutiny. ${ }^{4}$ This comment examines the basis for this departure from the rule against intervention. After reviewing the traditional rationales for nonintervention, the comment assesses the seminal New Jersey Supreme Court case of Falcone $v$. Middlesex County Medical Society. ${ }^{5}$ That case held that an association exercising monopoly power over a profession has a legal duty to act in a reasonable manner in making admission decisions. ${ }^{6}$ The com-

\section{(1975).}

1 Ascherman v. Saint Francis Memorial Hosp., 45 Cal. App. 3d 507, 119 Cal. Rptr. 507

2 Id. at 509, 119 Cal. Rptr. at 508. Ascherman's file contained 22 letters of reference from physicians not on the Saint Francis staff. Id. at 509 n.2, 119 Cal. Rptr. at 508 n.2.

3 Id. at 514, 119 Cal. Rptr. at 511.

- See infra note 12 and accompanying text.

34 N.J. 582, 170 A.2d 791 (1961).

- Id. at 591-96, 170 A.2d at 796-99. See infra notes 25-29, 36-37, and accompanying text. For contemporaneous commentary on Falcone, see Note, Judicially Compelled Admission to Medical Societies: The Falcone Case, 75 HArv. L. Rev. 1186 (1962) [hereinafter cited as Harvard Note]; Note, Expulsion and Exclusion from Hospital Practice and Organ- 
ment argues that Falcone rests on dubious ground, and it endeavors to develop a more principled test for intervention. Finally, the comment concludes that, even if the Falcone rationale is sound, decisions such as Ascherman have distorted its meaning and extended judicial involvement far beyond its legitimate bounds.

\section{The Traditional Rule}

Private associations have been part of American society since its inception." As Alexis de Tocqueville noted, "Americans of all ages, all conditions, and all dispositions constantly form associations."8 The Encyclopedia of Associations" lists almost 15,000 private associations at the national level alone. Thousands of these groups have state and local affiliates, and there are countless other local and regional associations.

Private professional associations perform a number of important functions. They provide library facilities, referral services, and opportunities for professional contacts and continuing education. In addition, they provide services to the public at large. For example, private associations can accredit professional schools, review qualifications of those who are considered for public office, and set professional standards for their members. Moreover, private associations that screen their members can provide a further service to the public. Membership in an association can give the layman an easy way to distinguish among professionals he would find otherwise indistinguishable. Other things being equal, the professional

ized Medical Societies, 15 RutaErs L. REv. 327 (1961) [hereinafter cited as Rutgers Note]; Note, The Physician's Right to Hospital Staff Membership: The Public-Private Dichotomy, 1966 WASH. U.L.Q. 485; Note, Exclusion from Private Associations, 74 YALE L.J. 1313 (1965).

7 "The Puritans who migrated to New England did so under the aegis of private companies with charters from the crown, one of the few instances in which a private government has had almost complete jurisdiction over a geographical area." C. GuB, HIDDEN HIERARchirs: The Prorgssions and Govgrnment 10 (1966). On the role of private associations in American history, see generally B. Blmdstein, Thr Culturg of Proprssionalism (1976); C. GilB, supra, at 10-52, 251-54; The Professions in Ambrica (K. Lynn ed. 1965).

- 2 A. De Tocqueville, Democracy in America 114 (P. Bradley trans. 1945). He continued:

[Americans] have not only commercial and manufacturing companies, in which all take part, but associations of a thousand other kinds, religious, moral, serious, futile, general or restricted, enormous or diminutive .... If it is proposed to inculcate some truth or to foster some feeling by the encouragement of a great example, they found a society. Wherever at the head of some new undertaking you see the government of France or a man of rank in England, in the United States you will be sure to find an association.

- 1 Gale Research Company, Encyclopedia of Associations (D. Akey 15th ed. 1980) [hereinafter cited as Encyclopedia or Associations]. 
who is a member of an exclusive professional organization will likely be more qualified than one who is not.10

The traditional rule is that courts will not intervene in the affairs of private professional associations, so that the associations will be able to serve these purposes effectively. ${ }^{11}$ Until the last two decades, this rule of nonintervention was axiomatically extended to private associations' admission decisions. ${ }^{12}$

In addition to the deep-rooted value of allowing individuals to associate with whomever they please, ${ }^{13}$ several other considerations support this rule. First, strong private associations are an important safeguard against excessive governmental power. Public supervision of private groups could foster a society in which diversity, freedom, and individual initiative were replaced by a bureaucratic state directing "what shall be orthodox"14 in every facet of daily life. As Professor Zechariah Chafee argued in 1930:

The health of society will usually be promoted if the groups within it which serve the industrial, mental, and spiritual needs of citizens are genuinely alive. Like individuals, they will usually do the most good if they are free to determine their own lives .... Legal supervision must often be withheld for fear that it may do more harm than good. The principle of freedom and growth is too easily overlooked by judges. ${ }^{15}$

10 For a more negative evaluation of the functions performed by private professional associations, see C. Gub, supra note 7, at 53-81.

11 See Medical Soc'y of Mobile County v. Walker, 245 Ala. 135, 138-40, 16 So. 2d 321, 324-25 (1944); Falcone v. Middlesex County Medical Soc'y, 62 N.J. Super. 184, 199, 162 A.2d 324, 329 (Super. Ct. Law Div. 1960), aff'd, 34 N.J. 582, 170 A.2d 791 (1961); State ex rel. Hartigan v. Monongalia County Medical Soc'y, 97 W. Va. 273, 276, 124 S.E. 826, 827 (1924); Developments in the Law-Judicial Control of Actions of Private Associations, 76 HaRv. L. Rev. 983, 1045-55 (1963) [hereinafter cited as Developments]; Annot., 137 A.L.R. 311 (1942).

12 See, e.g., Medical Soc'y of Mobile County v. Walker, 245 Ala. 135, 138-40, 16 So. 2d 321, 324-25 (1944); Moles v. White, 336 So. 2d 427, 429 (Fla. Dist. Ct. App. 1976); Trautwein v. Harbourt, 40 N.J. Super. 247, 260, 123 A.2d 30, 37 (Super. Ct. App. Div. 1956) ("The general rule is that there is no legal remedy for exclusion of . . . an individual from admission into a voluntary association, no matter how arbitrary or unjust the exclusion."); Huffaker v. Bailey, 273 Or. 273, 280-82, 540 P.2d 1398, 1401-02 (1975). See also Chafee, The Internal Affairs of Associations Not for Profit, 43 HARv. L. REv. 993, 1027-28 (1930); Rutgers Note, supra note 6, at 337.

1s See Healy v. James, 408 U.S. 169, 181 (1972); NAACP v. Alabama ex rel. Patterson, 357 U.S. 449, 460 (1959); L. Tribe, Ambrican ConstTtutional Law 974-80 (1978).

16 West Va. State Bd. of Educ. v. Barnette, 319 U.S. 624, 642 (1943) (involving the unrelated issue of compulsory salutes to the flag).

${ }^{15}$ Chafee, supra note 12, at 1027 (1930). See also Developments, supra note 11, at 990 ("Strict judicial supervision of the internal affairs of associations might be so burdensome as to hamper a group's functioning."). 
Second, courts lack the expertise to review the judgments of private associations. ${ }^{16} \mathrm{~A}$ court is ill-equipped to determine, for example, whether a physician with a particular educational background would be more valuable to a particular hospital than would another physician with different credentials. ${ }^{17}$ And although a private professional association inevitably will make occasional incorrect decisions, the costs of a judicially designed system for ensuring correct decisions in every case may be prohibitive. In other words, the association's admission procedure may be the most cost effective and socially efficient possible.

Finally, arbitrary exclusion of qualified applicants may be a self-correcting problem. If a professional association does not make admission decisions based on ability, membership will not be viewed as an indicium of quality in the profession, ${ }^{18}$ and rejected applicants will not be injured professionally. In such circumstances, other associations may be formed that more faithfully ensure quality in the profession.

There are, to be sure, statutory and constitutional limitations on the autonomy of private organizations. For example, the Supreme Court has held that the antitrust laws forbid bar associations from prescribing minimum attorney's fees schedules. ${ }^{19} \mathrm{Sec}-$ tion 703 of Title VII of the Civil Rights Act of 1964 forbids discrimination in employment on the bases of race, color, religion,

16 See Chafee, supra note 12, at 1024 (warning that judicial intervention would lead to a "dismal swamp," because courts have limited expertise and analytical competence compared with that of private groups). See also Developments, supra note 11, at 991; Harvard Note, supra note 6 , at 1194.

17 See Harvard Note, supra note 6, at 1194.

18 See Chafee, supra note 12, at 1027 ("A due regard for the corresponding interests of others is desirable, but must be somewhat enforced by public opinion.").

10 Goldfarb v. Virginia State Bar, 421 U.S. 773 (1975). Fee schedules were held to constitute horizontal price fixing in violation of section 1 of the Sherman Act, 15 U.S.C. $\$ 1$ (1976). 421 U.S. at 783, 786-88, 791. The general rule regarding price fixing is that "a combination formed for the purpose and with the effect of raising, depressing, fixing, pegging, or stabilizing the price of a commodity . . . is illegal per se." United States v. Socony-Vacuum Oil Co. (Madison Oil), 310 U.S. 150, 223 (1940). For an argument that the antitrust laws forbid only those price fixing agreements that reduce allocative efficiency, and thus should be construed to permit many forms of maximum price fixing, see Easterbrook, Maximum Price Fixing, 48 U. Chr. L. RBv. 886 (1981).

See also Bates v. State Bar, 433 U.S. 350 (1977), where the Arizona Supreme Court's regulation banning advertising by attorneys was attacked under the Sherman Act and the first amendment. The Court held that the regulation was state action and struck down the regulation on first amendment grounds. Id. at 384 . Horizontal price fixing principles might have been applied here had there been no state action, for a ban on advertising would seem to restrict attorneys' abilities to compete on the basis of price, thus facilitating agreements among them to maintain prices at a high level. 
sex, and national origin. ${ }^{20}$ And where a private group engages in "state action," the fourteenth amendment's due process clause ${ }^{21}$ may require judicial supervision of the group's membership practices. ${ }^{22}$

These limitations generally do not apply to the issue at hand. Decisions departing from the traditional rule of nonintervention have not rested on statutory considerations, and several of the opinions have emphasized that the defendant organizations were "nongovernmental" for purposes of the fourteenth amendment. ${ }^{23}$ Instead, courts intervening in the admission practices of private organizations have rested their decisions on common law principles and public policy concerns.

\section{Rationales for INTERVENTION}

The threshold requirement for judicial intervention is the breach of a legal duty. Focusing on Falcone v. Middlesex County Medical Society, ${ }^{24}$ this part examines and criticizes the asserted duty of a private professional association not to exclude qualified applicants from membership.

\section{A. Falcone}

Doctor Falcone received a Doctor of Osteopathy degree from a school not accredited by the American Medical Association ("AMA"), but he passed the New Jersey licensing examination and studied for seven months at an AMA-approved school in Italy, where he earned an M.D. degree. ${ }^{25}$ Despite these qualifications, the Middlesex County Medical Society ("Society") denied his application for active membership because of an unwritten by-law requiring all members to have been trained for four years at an AMAapproved school. Falcone sued the Society, and the New Jersey Supreme Court struck down the unwritten by-law as contrary to pub-

2042 U.S.C. $\$ 2000 \mathrm{e}-2$ (1976).

21 U.S. Const. amend. XIV, \& 1.

22 See infra notes 68-72 and accompanying text.

2s See, e.g., Pinsker v. Pacific Cosst Soc'y of Orthodontists, 12 Cal. 3d 541, 550 n.7, 526 P.2d 253, 259 n.7, 116 Cal. Rptr. 245, $251 \mathrm{n} .7$ (1974) (en banc) ("It is important to note that the legal duties imposed on defendant organizations arise from the common law rather than from the Constitution as such: ... the "due process" concept is applicable only its broadest, nonconstitutional connotation."); Greisman v. Newcomb Hosp., 40 N.J. 389, 396, 192 A.2d 817, 821 (1963); Davidson v. Youngstown Hosp. Ass'n, 19 Ohio App. 2d 246, 250 N.E.2d 892 (1969).

3434 N.J. 582, 170 A.2d 791 (1961).

2s Id. at 584-85, $170 \mathrm{~A} .2 \mathrm{~d}$ at 793. 
lic policy. ${ }^{28}$

The court justified its intervention by pointing to the effective monopoly power wielded by the Society: the AMA controlled the accreditation of all the hospitals in the region, and a prerequisite for accreditation was that all the physicians on the staffs of the hospitals be members of the Society. ${ }^{27}$ Therefore, the unwritten rule that excluded Falcone from the Society also effectively excluded him from practicing at any local hospital, because any hospital that had him on its staff would not be accredited by the AMA. The hospitals depended on accreditation to procure the services of physicians, interns, and nurses. ${ }^{28}$ The court argued that by virtue of this monopoly control, the Society's power was "to be exercised in a reasonable and lawful manner for the advancement of the medical profession and the public generally."29

The New Jersey Supreme Court relied on James v. Marinship Corporation, ${ }^{30}$ a California case involving the arbitrary refusal of a trade union to allow black laborers to become members. The California Supreme Court there held that because the union had closed-shop agreements with potential employers, binding the employers to hire only union members, ${ }^{31}$ the union owed all potential members a duty of fair dealing. ${ }^{32}$ The court analogized to the common law rule that one who pursued a "common calling," such as a common carrier, an innkeeper, or a blacksmith, was obliged to serve all comers reasonably. ${ }^{3 s}$ According to the court, those engaged in common callings historically enjoyed virtual monopolies over their services in their communities; courts thus imposed a legal duty on these individuals to exercise their monopoly power in a nonarbitrary, reasonable manner. ${ }^{34}$

Finding that a labor union with closed-shop agreements exer-

2c Id. at $598,170 \mathrm{~A} .2 \mathrm{~d}$ at 800 .

27 This fact was noted in the lower court's opinion. Falcone v. Middlesex County Medical Soc'y, 62 N.J. Super. 184, 203-05, 162 A.2d 324, 334-35 (Super. Ct. Law Div. 1960), aff'd, 34 N.J. 582, 170 A.2d 791 (1961).

2. Harvard Note, supra note 6, at 1192. Loss of AMA accreditation might also have jeopardized state accreditation. See infra note 67 and accompanying text.

20 34 N.J. at 597, 170 A.2d at 799.

so 25 Cal. 2d 721, 155 P.2d 329 (1944).

"See generally R. Gorman, Basic Text on Labor Law 641-42 (1976). Closed-shop agreements like the one in Marinship, where union membership is a precondition for both initial and continued employment, are now illegal under section 8(a)(3) of the Labor Management Relations Act, 29 U.S.C. § 158(a)(3) (1976).

32 25 Cal. $2 d$ at $731-33,155$ P.2d at 335-36.

33 Id. at 732, 155 P.2d at 335-36 (citing Wilson v. Newspaper \& Mail Deliverer's Union, 123 N.J. Eq. 347, 350, 197 A. 720, 722 (Ch. 1938)).

sId. 
cised similar monopoly control, ${ }^{35}$ the California court held that the union was likewise limited in its discretion in admitting members. Just as the only inn in town cannot arbitrarily refuse to rent a room to someone, leaving him without shelter for the night, so a union cannot arbitrarily refuse membership to a skilled craftsman, leaving him without a chance to pursue his calling.

The New Jersey Supreme Court in Falcone found that the Society had the same monopoly power as the union in Marinship and thus the same duty to use its power in a reasonable manner. ${ }^{36} \mathrm{Be}-$ cause the court found that the Society had acted arbitrarily in denying membership to Doctor Falcone, effectively depriving him of the chance to practice medicine, it voided the action and ordered the Society to accept Falcone as a member. ${ }^{37}$

\section{B. Criticisms of Falcone}

The common calling analogy employed in Marinship and Falcone can be attacked on several grounds. First, the analogy rests on a slender reed. The common law subjected a person to common calling status because he "held himself out to serve the public generally, making that his business, and in so doing assumed to serve all members of the public who should apply, and to serve them with care."38 It was because an individual represented that his services were available to all who chose to use them that he was classified as one engaged in a common calling..$^{30}$ Private associations, in contrast, do not hold themselves out to the public at large. They serve the public by being selective in membership rather than by being indiscriminately inclusive; if membership is to be an indicium of quality, standards and by-laws must be set, and exclusions

ss $I d$.

se 34 N.J. at 597,170 A.2d at 799.

37 Id. at 597-98, 170 A.2d at 800 .

3s Burdick, The Origin of the Peculiar Duties of Public Service Companies (pt. 1), 11 Colum. L. Rev. 514, 515 (1911) (footnotes omitted). See also L. Gorton, The Concrpt of the Common Carrier in Anglo-American Law 79, 80-81 (1971); 1 R. Hutchinson, A TreaTISE ON THE LAW OF Carriers 44 (3d ed. 1906); 9 AM. Jur. 2D Carriers \& 4, at 43 (1964) ("the dominant and controlling factor in determining the status of one as a common carrier is his . . . holding out"); Note, The Duty of a Public Utility to Render Adequate Service: Its Scope and Enforcement, 62 CoLUM. L. REv. 312, 314 (1962) ("Generally, the duty to offer service extends as far but no further than the company's undertaking . . . .") (footnote omitted).

39 Scholars have noted the tautology of this definition. See L. Gorton, supra note 38, at 11 ("he who holds himself out to the general public is a common carrier, and he who is a common carrier must hold himself out to carry for anybody who chooses to use him"); $1 \mathrm{R}$. Hutchinson, supra note 38 , at 59 . 
from membership must occur. One may question the wisdom and fairness of some associations' standards, but the questionable quality of a decision does not alone create an affirmative legal duty. One may point to instances of substantial harm resulting from an association's adverse decisions, but the weight of an interest is also insufficient in itself to create a duty to benefit that interest. ${ }^{40}$ Thus, unlike traditional common calling services, private associations do not meet the essential holding-out requirement.

Rather than focus on this requirement, Marinship and Falcone argued that the law of common calling was grounded on a different rationale: monopoly power over a matter that concerned the public. ${ }^{11}$ The argument that the status of common calling arose out of monopoly power is hotly contested, however. ${ }^{22}$ There is scant evidence for the view that "common" meant "monopolistic"; people classified at common law as those engaged in common callings-innkeepers, farriers, smiths, tailors, and the like-enjoyed no more of a monopolistic position than those not so classified, such as butchers and carpenters. ${ }^{4}$ Even if common calling professions ever did enjoy a monopolistic status, they have long since become competitive; nevertheless, their special duties survive.4 The reliance of Marinship and Falcone on monopoly power is therefore misplaced.

Moreover, if the courts are going to ground the rule of common calling on concerns of monopoly power, there is no apparent reason why the rule should not be applied to corporations and private educational institutions as well as to unions and professional

to This principle is a cornerstone of the criminal law, see, e.g., W. LAFAVE \& A. ScotT, Handbook on Criminal Law $\S 26$, at 183-87 (1972); of the civil law, see, e.g., W. Prosser, HANDBOOK OF THE LAW OF TORTS § 53, at 324-26 (4th ed. 1971); and of constitutional law, see, e.g., Board of Regents v. Roth, 408 U.S. 564, 570-571 (1972) ("to determine whether due process requirements apply in the first place, we must look not to the 'weight' but to the nature of the interest at stake").

1 See James v. Marinship Corp., 25 Cal. 2d 721, 731-32, 155 P.2d 329, 335 (1944); Falcone v. Middlesex County Medical Soc'y, 34 N.J. 582, 597, 170 A.2d 791, 799 (1961).

${ }^{12}$ Compare Adler, Business Jurisprudence, 28 HARv. L. Rav. 135, 156 (1914) ("Nowhere [in the common law] is monopoly suggested as the distinguishing characteristic ....") with Wyman, The Law of Public Callings as a Solution to the Trust Problem (pt. 1), 17 HARv. L. REv. 156, 161 (1903) ("virtual monopoly" is the "characterizing thing" of the law of public callings).

t3 Adler, supra note 42, at 149 . Wyman himself admits that only "circumstances . . . suggest" monopolistic status as the defining principle; nowhere in the cases is there explicit reliance on that status. Wyman, supra note 42 , at 161.

"See L. Gonton, supra note 38, at 102-05. For an analysis of and argument against the use of market power in determining common carrier status in the communications field, see Comment, Common Carriers Under the Communications Act, 48 U. CHI. L. Rev. 409, 413, 433-37 (1981). 
associations. Private universities that offer unique and valuable training in a given field apparently would meet the Marinship-Falcone definition of common calling status, thereby subjecting their admissions processes to possible judicial scrutiny. ${ }^{45}$ Boeing Aircraft, the only major employer of jet aircraft engineers in the $\mathrm{Pa}$ cific Northwest, would appear to be under a similar duty to act reasonably in making its hiring decisions. ${ }^{46}$ One observes no such special duty, however, even though Boeing probably wields as much power over the career of an individual engineer as the Society exerted over Doctor Falcone's career or as the trade union had over the career of the excluded worker. Courts intervening in the admission practices of private associations have offered no explanation for these disparities and no limiting principles that would prevent judicial scrutiny of all "important," "monopolistic" private activity.

There is a further problem with the monopoly-based definition: the Falcone line of cases have not defined "monopoly." In the area of antitrust law, this definitional problem is the subject of ongoing debate among lawyers, economists, and judges. ${ }^{47}$ In antitrust cases, the courts have developed a "relevant market" yardstick by which to measure possible monopoly power; ${ }^{48}$ that yardstick has two dimensions-the product market and the geographic market. The product market concept tests the definition of the product at issue, examines the "functional interchangeability" of that product with "market alternatives," and studies the crosselasticity of demand between the product and alternatives. ${ }^{48}$ The geographic market concept is a short-hand phrase used to describe

45 Private universities receiving federal assistance are under a statutory duty to refrain from discrimination in admissions based on race, color, or national origin, see Title VI of the Civil Rights Act of 1964, 42 U.S.C. § $2000 \mathrm{~d}$ (1976), or based on sex, see Title IX of the Education Amendments of 1972, 20 U.S.C. $\$ 1681$ (1976). These statutory duties apply to all universities receiving federal assistance, regardless of their size or the caliber of their academic programs.

48 Although Boeing is subject to statutory duties to refrain from employment discrimination, see, e.g., Title VII of the Civil Rights Act of 1964, 42 U.S.C. $\$ \S 2000 \mathrm{e}-2000 \mathrm{e}-17$ (1976), and to deal fairly with employees, see, e.g., Fair Labor Standards Act, 29 U.S.C. $\$ \S$ 201-219 (1976), such duties apply to corporations irrespective of their market share.

47 See, e.g., 2 P. AREeda \& D. TURner, Antitrust Law \$§ 500-528 (1978); R. Posner, Antitrust Law: An Economic Perspective 8 (1976); L. Sullivan, Handbook of the Law of ANTITRUST 33-40 (1977).

43 See generally Brown Shoe Co. v. United States, 370 U.S. 294, 336-37 (1962); 2 P. Areedn \& D. Turner, supra note 47, §§ 507, 517-58; L. Sullivan, supra note 47, §§ 12-21.

49 See, e.g., International Boxing Club, Inc. v. United States, 358 U.S. 242, 252 (1959); United States v. E.I. du Pont de Nemours \& Co., 351 U.S. 377, 394-404 (1956). 
the area within which the strength of competition is measured..$^{\mathrm{so}}$ Determining the relevant product and geographic markets is "a necessary predicate" to deciding whether economic activity violates the antitrust laws. ${ }^{51}$

One might argue that a county is much too small a geographic unit for evaluating the impact of a county medical society's adverse admission decision, for medical schools have nationwide referral services, and medical services are in demand throughout the country. Similarly, one could argue that a skilled tradesman denied membership in one union could pursue a variety of other callings. Although Marinship and Falcone present particularly compelling fact situations, their conclusionary uses of the monopoly concept are troubling.

Other possible justifications for judicial intervention in admission decisions of private associations are even weaker than the Falcone "common calling" rationale. As discussed in part II-C below, the fourteenth amendment's state action requirement precludes imposing procedural due process requirements on private associations in all but the rarest of cases. ${ }^{62}$ Similarly, potential plaintiffs would have great difficulty proving the tort of willful interference with prospective economic advantage because, in most cases, the intent element could not be proved.ss In addition, a rejected applicant would usually lack a cause of action under antitrust law because he would have difficulty showing the required injury to competition, as opposed to injury to a competitor. ${ }^{54}$

so See, e.g., United States v. Marine Bancorp., Inc., 419 U.S. 602, 620-21 (1974); United States v. Philadelphia Nat'l Bank, 374 U.S. 321, 359 (1963); Brown Shoe Co. v. United States, 370 U.S. 294, 336-37 (1962).

1 United States v. Marine Bancorp., Inc., 418 U.S. 602, 618 (1974).

62 See infra notes 68-72 and accompanying text.

s Harvard Note, supra note 6, at 1191-92. On the intent requirement, see W. Prosser, supra note $40, \S 129$, at 927-28; on the interference tort generally, see Perlman, Interference with Contract and Other Economic Expectancies: A Clash of Tort and Contract Doctrine, 49 U. CHI. L. REv. 61 (1982).

st See Brunswick Corp. v. Pueblo Bowl-O-Mat, 429 U.S. 477, 488 (1977) (Sherman Act protects "competition not competitors").

An older line of cases, not expressly overruled by Brunswick, holds that harm to individual competitors caused by monopolistic boycotts is sufficient to raise an antitrust claim. Klor's Inc. v. Broadway-Hale Stores, Inc., 359 U.S. 207 (1959); Kiefer-Stewart Co. v. Joseph E. Seagram \& Sons, 340 U.S. 211 (1951). A private association sued under this theory could probably defend itself successfully on two grounds. First, it is difficult to point to a boycott in the exclusion cases. In Falcone, unless the hospitals in the county got together and agreed that all must be accredited, the fact that all sought AMA accreditation seems simply to represent a choice made by each hospital. In the Ascherman situation, it is even more clear that the hospital was acting alone and not as part of a boycott. Second, a medical society, for example, that was sued under the boycott theory could probably argue successfully that 
Another alternative rationale to the one in Falcone is that exclusion from a society imposes an injury that is in substance no different from explusion; because expulsion has been subjected to judicial scrutiny, ${ }^{\mathrm{s5}}$ exclusion should be reviewed under the same standard. The flaw in this argument is that the similarity of the injury in the two cases does not establish the existence of the same legal duty. The willingness of courts to intervene when an individual is expelled from an organization stems from a legal relationship existing between an individual and an association to which he belongs. Some of the resulting rights are palpable. For example, a member of an association may have a right to share in the physical assets of the association if it dissolves. ${ }^{56}$ Other rights are essentially contractual. When an individual joins an association, the individual and the association enter into a contract with one another, and an implicit term in the contract that cannot be waived is a duty of fair dealing. ${ }^{57}$ An association that arbitrarily expels an individual arguably violates this duty. Even if one does not rely explicitly on notions of property or contract rights, the obligations of an association to members necessarily differ from its duties to outsiders with whom it has never dealt. A general duty to treat all strangers on the same basis as members of a group is inconsistent with the principle that individuals should be free to associate with whomever they please. ${ }^{88}$ This is not, of course, to say that an association should have no duties in its dealings with strangers, but only that whatever the duty is, it is different from (and lesser than) its duties to those with whom it has established relationships.

the relevant market for physician's services is nationwide. See supra notes $48-52$ and accompanying text. Thus, a society's ability to prevent a physician from practicing in a given county would not constitute an effective monopolistic restraint for purposes of the antitrust laws.

5s See, e.g., Van Daele v. Vinci, 51 Ill. 2d 389, 282 N.E.2d 728, cert. denied, 409 U.S. 1007 (1972); Virgin v. American College of Surgeons, 42 Ill. App. 2d 352, 369, 192 N.E.2d 414, 422-23 (1963); State ex rel. O’Brien v. Petry, 397 S.W.2d 1, 6 (Mo. Ct. App. 1965); Higgins v. American Soc'y of Clinical Pathologists, 51 N.J. 191, 238 A.2d 665 (1968); Annot., 89 A.L.R.2d 964 (1963); Annot., 20 A.L.R.2d 531 (1951).

so See Developments, supra note 11, at 999-1001.

s7 See Burton, Breach of Contract and the Common Law Duty to Perform in Good Faith, 94 Harv. L. REv. 369, 369 (1980):

A majority of American jurisdictions, the Restatement (Second) of Contracts [§ 231], and the Uniform Commercial Code $[\$ 1-203]$. . . now recognize the duty to perform a contract in good faith as a general principle of contract law. The conduct of virtually any party to any contract accordingly may be vulnerable to claims of breach stemming from this obligation.

see supra note 13 and accompanying text. 


\section{A Proposed Analysis}

The one promising avenue in defense of the results in Marinship and Falcone is to analyze the extent to which a private group's power derives directly from governmental support. For example, a private university's preeminence in a given field results from the school's own efforts in hiring faculty and encouraging research. Similarly, Boeing has achieved its strength through market forces such as economies of scale: ${ }^{58}$ the reason there is only one major manufacturer of large jet aircraft in the Pacific Northwest is that the world's economy justifies only a few such firms.

On the other hand, a union and a medical society are powerful largely because of governmental intervention on their behalf. For example, although the government prohibits price-fixing agreements among sellers of goods, ${ }^{60}$ it permits similar efforts by union members to sell their services to employers at a uniform price. ${ }^{61}$ Moreover, the government supervises a union's elections, ${ }^{62}$ ensures that the employer will bargain with it, $^{6 s}$ and guarantees it an exclusive monopoly of representation. ${ }^{84}$

Similarly, the medical society in Falcone was powerful because of its ties with the AMA, which performs a quasi-licensing function by accrediting hospitals and imposing uniform standards on them. ${ }^{\text {es }}$ Although one could argue that such activities are private, they are closely intertwined with governmental functions; lack of accreditation can be the "kiss of death":"8s

Private accrediting activities would be far less effective if it were not for public laws recognizing and enforcing the pri-

s2 See, e.g., United States v. United Shoe Mach. Corp., 110 F. Supp. 295, 342, 345 (D. Mass.) (Wyzanski, J.) (dictum) (defendant could escape antitrust liability if it proved its monopoly power arose solely from superior skill, natural advantages, better products, economic or technical efficiency, or "economically inevitable" factors), aff'd per curiam, 347 U.S. 521 (1953); In re E.I. du Pont de Nemours \& Co., 96 F.T.C. 705, 747-48 (1980) (corporation excused from antitrust liability because its power resulted from efficiency).

*o The general rule is that such agreements are per se illegal, on the theory that they constitute a "threat to the central nervous system of society." United States v. SoconyVacuum Oil Co. (Madison Oil), 310 U.S. 150, 223, 226 n.59 (1940). See supra note 54.

"Apex Hosiery v. Leader, 310 U.S. 469, 503-04 (1940) ("[A]n elimination of price competition based on differences in labor standards is the object of any national labor organization. But this effect of competition has not been considered to be the kind of curtailment of price competition prohibited by the Sherman Act.").

-2 National Labor Relations Act, § 9(b)-(e), 29 U.S.C. § 159(b)-(e) (1976).

os Id. \$ 8(a)(5), 29 U.S.C. \& 158(a)(5) (1976).

or Id. \& 9(a), 29 U.S.C. \$ 159(a) (1976).

as See supra notes $27-28$ and accompanying text.

c6 C. GuB, supra note 7, at 59. 
vate standards. Many professions have persuaded their state legislatures to write into state licencing laws requirements that professional education be in an accredited school or college, or give some form of special advantage to those with preparation in such institutions .... States have rarely accredited hopitals not approved by the AMA. Even when state boards have done their own accrediting, they have usually paid close attention to the professional association's recommendations. ${ }^{67}$

By filling a function that might have been filled by a state body, an association such as the AMA might find itself under a special obligation to act in a nonarbitrary manner.

Many of the concerns discussed here are factors that have been considered-and rejected-in the fourteenth amendment state action context. For example, in Jackson $v$. Metropolitan Edison Co., ${ }^{68}$ the Supreme Court considered a claim against a privately owned utility that had terminated a customer's electric service for nonpayment without adequate notice and a hearing. Metropolitan Edison provides a vital public service, is a monopoly licensed by the government, is subject to pervasive governmental regulation, and offers a service that many governmental units provide themselves. ${ }^{69}$ Nevertheless, the Court rejected all claims of state action. It held that, absent direct state support for the specific practice under challenge, state conferral of monopoly status is insufficient to meet the "encouragement" and "authorization" branch of state action doctrine. ${ }^{70}$ It also held that a private entity performs a "public function," thereby meeting the state action requirement, only where it exercises "powers traditionally exclusively reserved to the state." F1 Finally, the Court rejected application of

${ }^{62}$ Id. Many private associations cultivate governmental assistance in their attempts to control qualifications, preparation, entry, and practice in their professions. See id. at 134-40. See generally Note, The American Medical Association: Power, Purpose and Politics in Organized Medicine, 63 YALE L.J. 937 (1954).

c8 419 U.S. 345 (1974).

69 See id. at $350-51$; id. at 362 (Douglas, J., dissenting); id. at 366-68 (Marshall, J., dissenting).

${ }^{70}$ Id. at 351-52. See also Reitman v. Mulkey, 387 U.S. 369 (1967) (holding unconstitutional a state constitutional amendment that made private discrimination in real estate transactions immune from state regulation).

${ }^{11} 419$ U.S. at 352-53. See also Flagg Bros., Inc. v. Brooks, 436 U.S. 149 (1978) (sale of goods to satisfy a warehouseman's lien not a public function); Hudgens v. NLRB, 424 U.S. 507 (1976) (shopping center does not meet public function doctrine requirements; effectively overruling previous cases); Evans v. Newton, 382 U.S. 296 (1966) (public park that reverted to private ownership still performed a public function because its "predominant character 
the "significant state involvement" strand of state action doctrine, finding no "symbiotic relationship" between the state's regulation of the utility and the utility's termination practices. ${ }^{72}$

The elements of constitutional state action analysis-cencouragement" and "authorization," "public function," and "significant state involvement"-offer a useful framework in the search for a nexus between governmental activity and a private association's power over professional careers. These elements, however, need not be given the same circumscribed meaning in the common law context as in the fourteenth amendment context, for the two serve different functions. ${ }^{73}$ In "common law state action" analysis, relevant factors would include whether an association's monopoly power resulted from governmental authorization and exclusion of others; the degree of governmental regulation; whether the function performed by the association would otherwise be undertaken by the state; and the degree to which the state relied on the association's decision in its own decisionmaking.

If courts are to intervene in private associations' admission decisions, the most reasoned approach might be by way of a threestep analysis. A court should first determine the relevant geographical and product markets ${ }^{74}$ and whether, within those markets, the private association exercises monopoly power. The court should then consider the nexus between the association's monopoly position and state action. Finally, it should balance the plaintiff's deprivation against the traditional reasons for nonintervention: respect for private autonomy, an association's greater expertise, and the

and purpose . . . [were] municipal"); Terry v. Adams, 345 U.S. 463 (1953) (pre-general election selection of candidates for public office a public function); Marsh v. Alabama, 326 U.S. 501 (1946) (company town serves public function).

72419 U.S. at 357-58. On the state involvement doctrine, see Shelley v. Kraemer, 334 U.S. 1 (1948) (judicial enforcement of racially restrictive covenants unconstitutional). The potentially broad implications of Shelley have been narrowed substantially. See, e.g., Evans v. Abney, 396 U.S. 435 (1970) (permissible for courts to enforce racially motivated reverter clause in charitable trust). See also Burton v. Wilmington Parking Auth., 365 U.S. 715 (1961) (racially segregated coffee shop leased from state agency met state action requirement).

73 State action is required in the constitutional context because the fourteenth amendment reaches only actions that can be attributed to the state itself; the amendment does not authorize the creation of a "code of municipal law for the regulation of private rights." Civil Rights Cases, 109 U.S. 3, 11 (1883). States may engage in such regulation, however, and a "common law state action" requirement would merely serve to ensure that private power was sufficiently attributable to direct state intervention 80 that imposing duties of fair dealing in return for that support would be appropriate.

${ }^{74}$ See supra notes $48-51$ and accompanying text. 
possibility of self-correction through market forces. ${ }^{75}$ This threestep test would narrowly circumscribe instances of judicial intervention in private associations' admission decisions, and rightly so: the alternative Falcone approach is self-expanding, historically fallacious, and fails to respect private autonomy.

\section{Defining the Required Deprivation}

Courts intervening in the admission decisions of private organizations have almost uniformly relied on the Falcone rationale. ${ }^{78}$ Jurisdictions differ, however, on the limits of that doctrine. Illinois is typical of jurisdictions whose courts have taken a narrow view of intervention by holding that deprivation of anything short of an economic necessity does not warrant judicial intervention. ${ }^{77}$ Illinois courts have therefore denied a right of action where a doctor was not allowed membership in the American Association of Orthopedic Surgeons. ${ }^{78}$ Membership was a factor relied on by hospitals in granting hospital privileges and by insurance companies in setting malpractice rates, ${ }^{79}$ but, unlike Falcone, hospitals would not jeopardize their accreditation by accepting a nonmember on their staffs. $^{80}$ Moreover, in a case almost identical to Ascherman, an Illinois court refused to intervene where a doctor who was affiliated with several hospitals was denied privileges at a more conveniently located hospital. ${ }^{81}$

California courts take a much more expansive view of intervention, holding that they can review a private association's admis-

7s See supra notes 13-18 and accompanying text.

76 See, e.g., Blende v. Maricopa County Medical Soc'y, 96 Ariz. 240, 393 P.2d 926 (1964); Pinsker v. Pacific Coast Soc'y of Orthodontists, 1 Cal. 3d 160, 460 P.2d 495, 81 Cal. Rptr. 623 (1969); Triester v. American Academy of Orthopedic Surgeons, 78 Ill. App. 3d 746, 396 N.E.2d 1225 (1979), appeal denied, 79 III. 2d 630 (1980); Salter v. New York State Psychological Ass'n, 14 N.Y.2d 100, 198 N.E.2d 250, 248 N.Y.S.2d 867 (1964); Davidson v. Youngstown Hosp. Ass'n, 19 Ohio App. 2d 246, 250 N.E.2d 892 (1969).

${ }_{77}$ See, e.g., Triester v. American Academy of Orthopedic Surgeons, 78 Ill. App. 3d 746, 755, 396 N.E.2d 1225, 1231 (1979), appeal denied, 79 Ill. 2d 630 (1980). Other states observing a similarly restrictive view of intervention include Florida, Moles v. White, 336 So. 2d 427 (Fla. Dist. Ct. App. 1976); Monyek v. Parkway Gen. Hosp., Inc., 273 So. 2d 430 (Fla. Dist. Ct. App. 1973); and New York, Salter v. New York State Psychological Ass'n, 14 N.Y.2d 100, 198 N.E.2d 250, 248 N.Y.S.2d 867 (1964).

78 Triester v. American Academy of Orthopedic Surgeons, 78 Ill. App. 3d 746, 396 N.E.2d 1225 (1979), appeal denied, 79 III. 2d 630 (1980).

70 Id. at 748-49, 396 N.E.2d at 1227.

so Id. at 755,396 N.E.2d at 1232.

s1 Jain v. Northwest Community Hosp., 67 Ill. App. 3d 420, 385 N.E.2d 108 (1978), appeal denied, 75 Ill. 2d 591 (1979). 
sion decisions whenever membership is a "practical necessity,"82 without which an individual could not "realize maximum potential achievement and recognition" in his chosen profession. ${ }^{83}$ California courts have therefore intervened where the harm has been simply to withhold referral of patients to the plaintiff ${ }^{84}$ and, in $A s-$ cherman, where the plaintiff was prevented from practicing at one of many San Francisco hospitals. ${ }^{85}$

The California standard effectively is no standard at all. Membership in an association always imparts benefits-recognition, education, contacts, fraternity-to its members; that is the purpose for its existence. Exclusion of any applicant from any association reduces his chances for "maximum potential achievement." For example, a traveling shoe salesman presumably would find membership in the National Shoe Traveler's Association valuable; that group sponsors twenty regional shoe shows each spring and fall, holds training seminars for members, and publishes a newsletter. ${ }^{86}$ And a surplus goods dealer would be well-advised to join the Associated Surplus Dealers, a group that promotes trade shows, serves as a valuable liaison with government agencies, offers group insurance coverage, recognizes achievement through member awards, and publishes newsletters and catalogues. ${ }^{87}$ Applicants rejected from these and thousands of other private groups could plausibly argue that exclusion reduced their possibilities for "maximum potential achievement and recognition" in their fields.

Though purporting to rely on Falcone, the expansive California view focuses only on the extent of the harm involved in a given exclusion; hence the emphasis on "maximum potential achievement." Properly read, the Falcone rationale supports a special legal duty only as a function of an organization's monopoly power over an individual's professional livelihood. The Society in that

as Pinsker v. Pacific Coast Soc'y of Orthodontists, 1 Cal. 3d 160, 166, 460 P.2d 495, 499, 81 Cal. Rptr. 623, 627 (1969).

o3 Id. Other states apparently embracing this more expansive view of intervention include New Jersey, Greisman v. Newcomb Hosp., 40 N.J. 389, 192 A.2d 817 (1963); Arizona, Blende v. Maricopa County Medical Soc'y, 96 Ariz. 240, 393 P.2d 926 (1964); and Ohio, Davidson v. Youngstown Hosp. Ass'n, 19 Ohio App. 2d 246, 250 N.E.2d 892 (1969).

* Pinsker v. Pacific Coast Soc'y of Orthodontists, 1 Cal. 3d 160, 166, 460 P.2d 495, 498, 81 Cal. Rptr. 623, 626 (1969).

es Ascherman v. Saint Francis Memorial Hosp., 45 Cal. App. 3d 507, 119 Cal. Rptr. 507 (1975); see supra text accompanying notes 1-3.

se See 1 Encyclopedis of Associations, supra note 9, at 228, entry 2834. The association has 6600 members. Id.

*7 See id. at 230 , entry 2860 . The group has 400 members and is open to "[s]urplus dealers, general merchandise dealers, close-out dealers, manufacturers, manufacturers' representatives, and others." Id. 
case had the ability to deny Doctor Falcone the right to practice medicine in the county because of the accreditation standards its parent organization imposed on hospitals in the area. ${ }^{88}$ Because of this absolute power over Falcone's professional livelihood, a special duty was imposed on the Society that outweighed, in the court's view, the benefits flowing from nonintervention. ${ }^{89}$

Most associations, by contrast, do not wield such absolute power over the professional destinies of applicants. An orthodontist society's ability to reduce the number of referrals received by an orthodontist who is denied membership, ${ }^{90}$ and the ability to cause Doctor Ascherman inconvenience in not being able to work at one hospital, ${ }^{91}$ do not cause the sorts of injuries that give rise to a special legal duty. ${ }^{92}$ Such harms necessarily flow from the existence of private associations with selective admission standards. Moreover, the amount of harm erroneously inflicted is not likely to be large in the aggregate because such associations can flourish only when the standards they use for admission benefit the public at large.

The general forces of the market will not prevent all arbitrary acts of exclusion. Market forces would not, for example, prevent medical societies from excluding those who testify as expert witnesses for plaintiffs in medical malpractice actions. But the defects in a legal regime featuring intervention only when an association exercises power like that in Falcone may be fewer than the defects of a regime that allows intervention whenever a denial of membership inflicts significant injury.

Salter v. New York State Psychological Association ${ }^{93}$ provides a useful example. Salter was a practicing psychologist denied membership in the New York State Psychological Association because he did not meet the group's requirement that members have done graduate work in psychology to qualify. ${ }^{94}$ Salter had graduated

ss See supra notes 27-28 and accompanying text.

89 Falcone v. Middlesex County Medical Soc'y, 34 N.J. 582, 597, 170 A.2d 791, 799 (1961).

oo See, e.g., Pinsker v. Pacific Coast Soc'y of Orthodontists, 1 Cal. 3d 160, 460 P.2d 495, 81 Cal. Rptr. 623 (1969).

${ }^{91}$ Ascherman v. Saint Francis Memorial Hosp., 45 Cal. App. 3d 507, 119 Cal. Rptr. 507 (1975).

${ }^{82}$ See also Blatt v. University of S. Cal., 5 Cal. App. 3d 935, 85 Cal. Rptr. 601 (1970) (law student who attended night school not admitted to Order of the Coif, although his grades would have warranted admission had he been a day student; no judicially enforceable right to admittance).

93 14 N.Y.2d 100, 198 N.E.2d 250, 248 N.Y.S.2d 867 (1964).

94 Id. at 103,198 N.E.2d at 251,248 N.Y.S.2d at 868. 
from college and had gone directly into practice before New York passed a licensing law requiring graduate work in psychology for all practitioners. ${ }^{.5}$ The law contained a "grandfather clause" that allowed those in practice for a certain number of years to continue practicing without obtaining any advanced training; ${ }^{96}$ the association, however, made no such exception. ${ }^{97}$

The association had no effective licensing power similar to that of the medical society in Falcone. Membership in it was valuable to practitioners, because in addition to the services it provided and the ability it had to speak for the profession in setting standards, membership itself was a credential that signaled superior skill. Anyone denied membership suffered economic harm, but the harm resulted from the respect the public gave to the judgment of the society rather than from monopoly power that the society exercised. The New York Court of Appeals adhered to the restrictive standard, found no economic necessity, and dismissed the case. ${ }^{99}$ California courts would probably have reached a different result. Indeed, the harm suffered here seems as great, if not greater, than that suffered by Doctor Ascherman. ${ }^{100}$

Courts, however, are poorly situated to second-guess the procedures a society uses to judge potential members. It does not seem unreasonable to think that whether a psychologist has done graduate study bears some relationship to his skills. Although a society might not be able to expel members without such training, ${ }^{101}$ it would seem that it should be able to make such a judgment about applicants without having to justify its decisions in a courtroom.

\section{CoNCLUSION}

Setting limits on judicial intervention in the admission decisions of private organizations has led to considerable confusion. This comment has attempted to cut through this confusion to establish a principled framework for analysis. The Marinship-Fal-

os 1956 N.Y. Laws 1626-1629, ch. 737, §§ 7601, 7605(d) (repealed 1971).

os 1959 N.Y. Laws 1151, ch. 374, \& 7605(5) (repealed 1971).

97 N.Y.2d at 103,198 N.E.2d at 251,248 N.Y.S.2d at 869.

28 That harm would include the decrease in the number of patients who came to him because of public recognition that the association had refused to endorse him and fewer referrals to him from members of the association. If the public viewed him as being less capable, a rejected applicant also might be forced to charge lower prices.

20 14 N.Y.2d at 107,198 N.E.2d at 253,248 N.Y.S.2d at 872.

${ }^{100}$ See supra notes 1-3 and accompanying text.

101 See supra notes 55-57 and accompanying text. 
cone common calling analysis should be discarded: private associations are not analogous to common calling endeavors, and the monopoly rationale is historically inaccurate and without limiting principles. Rather, if courts are to intervene, an analysis along the lines of the approach offered in part II-C should be employed. A court should determine first, whether an association in fact exercises virtual monopoly power over an activity; second, whether there is a sufficiently strong nexus between that private power and state action in support of the association; and finally, whether the exclusion deprives an individual of all opportunities to pursue his professional livelihood in the relevant market. A broader standard would lead to inappropriate and possibly dangerous judicial intervention in private associational activities.

Robert S. Trefny 